\title{
Zgrzewanie rezystancyjne doczołowe zwarciowe w obliczeniach MES materiałów jednoimiennych - część 1
}

\author{
Resistance Butt Welding of Similar Materials \\ in FEM Calculations - part 1
}

\section{Streszczenie}

W artykule przedstawiono analizę procesu zgrzewania rezystancyjnego doczołowego zwarciowego prętów na przykładzie stali niskowęglowej (AISI 1008/W. nr1.0338:C-0.10\%, Mn-0.40\%) i średnicy $6 \mathrm{~mm}$. Przeprowadzono obliczenie numeryczne dla warunków brzegowych, jakie określono w pracy [1]. Na tej podstawie przeprowadzono dalsze obliczenia dla innych wariantów tj.: niższego prądu zgrzewania (przypadek często występujący w praktyce przemysłowej) oraz dla różnego ukształtowania (przygotowania) powierzchni czołowej zgrzewanych prętów. Obliczenia prowadzono dla jednoimiennej konfıguracji połączeń.

Słowa kluczowe: zgrzewanie doczołowe rezystancyjne, modelowanie MES,

\section{Abstract}

The article presents the analysis of resistance butt welding of rods made of low-carbon steel (AISI 1008/W. no. 1.0338:C-0.10\%, Mn-0.40\%) ( $\varnothing 6 \mathrm{~mm})$. The tests required carrying out numerical calculations for the boundary conditions determined in the work [1]. The numerical calculation results were the basis for further calculations concerned with other variants, i.e. lower welding current (a case frequent in industrial practice) and for variously shaped (prepared) butting faces of rods to be welded. Calculations were performed for the similar configuration of joints.

Keywords: Resistance Butt Welding, FEM calculations, numerical calculations

\section{Wstęp}

Zalecenia dotyczące zgrzewania rezystancyjnego zawarte są w Poradniku Spawalnictwa tom 2 [1] i dotyczą gęstości prądu zgrzewania $\left[\mathrm{A} / \mathrm{mm}^{2}\right]$, czasu zgrzewania [ms], jednostkowego docisku [daN/mm²], naddatku materiału na skrócenie elementów zgrzewanych [mm] i długość mocowania prętów zgrzewanych [mm]. Parametry podane w poradniku są zależne od średnicy zgrzewanych prętów i rodzaju materiału. Dla (analizowanej) stali niskowęglowej są one następujące:

- gęstość prądu zgrzewania $j_{\text {zgrz }}=(200-600)\left[\mathrm{A} / \mathrm{mm}^{2}\right]$,

- czas zgrzewania $t_{\mathrm{zgrz}}=0.1-15.0$ [sek],

- docisk jednostkowy $P=(0.5-5.0)\left[\mathrm{daN} / \mathrm{mm}^{2}\right]$,

- naddatek na skrócenie (spęczanie) materiałów $\Delta s=(0.15-0.7) \mathrm{d}[\mathrm{mm}]$ (rys. 1),

- długość wysunięcia pręta ze szczęk $l z=(0.5-1.5) d$ [mm] (rys. 1),

gdzie d - średnica pręta

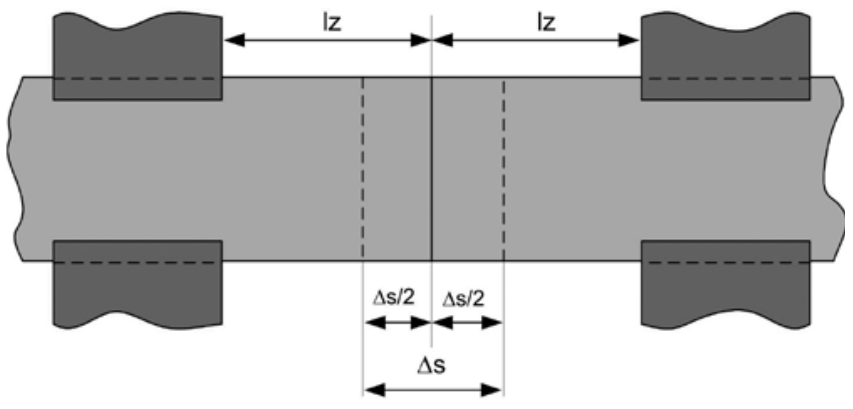

Rys. 1. Usytuowanie zgrzewanych materiałów

Fig. 1. Positioning of materials to be welded

Dla zalecanych wartości obliczono podstawowe parametry zgrzewania tj. wartość prądu zgrzewania i wartość siły docisku. Wyniki zestawiono w tablicy I dla dwóch średnic prętów 8 i $6 \mathrm{~mm}$.

Dr inż. Zygmunt Mikno - Instytut Spawalnictwa Gliwice, dr inż. Zbigniew Bartnik - Politechnika Wrocławska. 


\begin{tabular}{|c|c|c|c|c|c|c|c|c|c|}
\hline & & & & $\varnothing$ & 8 & $\mathrm{~mm}$ & $\varnothing$ & 6 & $\mathrm{~mm}$ \\
\hline & & \multicolumn{2}{|c|}{ Wartość } & S & 50 & $\mathrm{~mm}^{2}$ & S & 28 & $\mathrm{~mm}^{2}$ \\
\hline \multicolumn{2}{|c|}{ Parametry zgrzewania } & $\min$ & $\max$ & I[mm] & $P[\mathrm{daN}]$ & $\mathrm{i}[\mathrm{A}]$ & I[mm] & $P[\mathrm{daN}]$ & $\mathrm{i}[\mathrm{A}]$ \\
\hline gęstość prądu & $j=(200-600) A / \mathrm{mm}^{2}$ & 200 & 600 & 4 & 25 & 10000 & 3 & 14 & 5600 \\
\hline czas zgrzewania & $\mathrm{tz}=0,1-15,0$ sek & - & - & 4 & 250 & 10000 & 3 & 140 & 5600 \\
\hline docisk jednostk. & $P=0,5-5,0 \mathrm{daN} / \mathrm{mm}^{2}$ & 0,5 & 5,0 & 4 & 25 & 10000 & 3 & 14 & 5600 \\
\hline skrócenie & $\Delta s=(0.15-0.7) d$ & 0,15 & 0,7 & 4 & 250 & 10000 & 3 & 140 & 5600 \\
\hline długość prętów & $I z=(0.5-1.5) d$ & 0,5 & 1,5 & 12 & 25 & 30000 & 9 & 14 & 16800 \\
\hline \multirow{2}{*}{$\begin{array}{c}\text { powierzchnia } \\
\text { czołowa }\end{array}$} & $\emptyset=8 \mathrm{~mm}, \mathrm{~S}=50 \mathrm{~mm}^{2}$ & & & 12 & 250 & 30000 & 9 & 140 & 16800 \\
\hline & $\emptyset=6 \mathrm{~mm}, \mathrm{~S}=28 \mathrm{~mm}^{2}$ & & & 12 & 25 & 30000 & 9 & 14 & 16800 \\
\hline & & & & 12 & 250 & 30000 & 9 & 140 & 16800 \\
\hline
\end{tabular}

Obliczenia prowadzono dla czasu w którym:

- nastąpiło nadtopienie materiału na całym przekroju poprzecznym prętów, lub

- temperatura w wybranych punktach w obszarze styku prętów zgrzewanych osiągnęła temperaturę $1400{ }^{\circ} \mathrm{C}$ (co pozwala na uzyskania połączenia o odpowiedniej wytrzymałości),

- przekroczono założoną wartość skrócenia prętów $(0.7 d)$.

\section{Model obliczeniowy}

Model obliczeniowy zgrzewania doczołowego prętów, siatką elementów skończonych w obszarze zgrzewania przedstawiono dla kolejno analizowanych przypadków odpowiednio na rysunkach $1 \mathrm{a}_{0}, 1 \mathrm{~b}_{0}, 3 \mathrm{c}_{0}$, $3 \mathrm{~d}_{0}, 4 \mathrm{e}_{0} \div \mathrm{h}_{0}, 5 \mathrm{i}_{0}$.

Obliczenia prowadzono dla stali AISI 1008. Badania weryfikujące prowadzono dla stali S235JR będącego jej odpowiednikiem - o składzie wg PN-EN 10025:2002 - C max $0,1 \%$, Mn $\max 1,4 \%, \mathrm{P} \max 0,045 \%$, S max $0,045 \%, N$ max $0,009 \%$.

Obliczenia prowadzono w oparciu o model 2D z ok. 1000 stopni swobody. Prowadzona była analiza zjawisk elektrycznych, termiczno-metalurgicznych oraz mechanicznych. Do obliczeń wykorzystano oprogramowanie SORPAS [2].

W oparciu o normy i zalecenia przyjęto standardowe parametry zgrzewania $[1,2]$ :

- natężenie prądu $5.6 \div 16.8 \mathrm{kA}$,

- czas przepływu prądu zależny od przyjętych warunków analizy procesu (przetopienie, uzyskanie temperatury $1400^{\circ} \mathrm{C}$, przekroczenie maksymalnego dopuszczanego skrócenia elementów),

- siła docisku elektrod P = 14 daN - 140 daN,

Dla przyjętych parametrów nominalnych natężenia prądu i siły docisku przeprowadzono analizę dla skrajnych warunków procesu:

- (000) $\mathrm{i}=5.6 \mathrm{kA}, \mathrm{P}=14 \mathrm{daN}, \mathrm{I}_{1}=\mathrm{I}_{2}=12 \mathrm{~mm}$ (wysuniecie pręta ze szczęk mocujących),

- (001) $i=5.6 \mathrm{kA}, P=140 \mathrm{daN}$, pozostałe parametry jw.,

- (010) $\mathrm{i}=16.8 \mathrm{kA}, \mathrm{P}=14 \mathrm{daN}$, pozostałe parametry jw.,

- $(011) \mathrm{i}=16.8 \mathrm{kA}, \mathrm{P}=140 \mathrm{daN}$, pozostałe parametry jw.,

- $(100) \mathrm{i}=5.6 \mathrm{kA}, \mathrm{P}=14 \mathrm{daN}, \mathrm{I}_{1}=\mathrm{I}_{2}=4 \mathrm{~mm}$ (symetria $4 \mathrm{~mm}+4 \mathrm{~mm})$,

- (101) $\mathrm{i}=5.6 \mathrm{kA}, \mathrm{P}=140 \mathrm{daN}$, pozostałe parametry jw.,

- (110) $\mathrm{i}=16.8 \mathrm{kA}, \mathrm{P}=14 \mathrm{daN}$, pozostałe parametry jw.,

- (111) $\mathrm{i}=16.8 \mathrm{kA}, \mathrm{P}=140 \mathrm{daN}$, pozostałe parametry jw.. oraz dodatkowo dla innych wybranych wariantów zgrzewania:

- symetria zmocowania prętów $I_{1}=I_{2}=12 \mathrm{~mm}, P=80$ daN i różne prądy zgrzewania:

- (b1) $i=1.5 \mathrm{kA}$,

- (b2) $i=2.0 \mathrm{kA}$,

- (b3) $i=3.0 \mathrm{kA}$,

- (b4) $i=4.0 \mathrm{kA}$.

- zaostrzona krawędź czołowa prętów (kąt $\alpha=110^{\circ}$ ), symetria zmocowania $I_{1}=I_{2}=12 \mathrm{~mm}, P=80$ daN i różne prądy zgrzewania:

- (c1) $\mathrm{i}=1.5 \mathrm{kA}$,

- (c2) $i=2.0 \mathrm{kA}$,

- (c3) $i=3.0 \mathrm{kA}$,

- (c4) $i=4.0 \mathrm{kA}$.

- niesymetryczne zamocowanie, $\mathrm{P}=80 \mathrm{daN}, \mathrm{i}=5.6 \mathrm{kA}$ :

- (e1) $\mathrm{I}_{1}=12 \mathrm{~mm}, \mathrm{I}_{2}=6 \mathrm{~mm}$,

- (e2) $\mathrm{I}_{1}=12 \mathrm{~mm}, \mathrm{I}_{2}=4 \mathrm{~mm}$,

- (e3) $\mathrm{I}_{1}=12 \mathrm{~mm}, \mathrm{I}_{2}=2 \mathrm{~mm}$,

- (e4) $\mathrm{I}_{1}=12 \mathrm{~mm}, \mathrm{I}_{2}=1 \mathrm{~mm}$,

- niesymetryczne zamocowanie $\mathrm{I}_{1}=12 \mathrm{~mm}, \mathrm{I}_{2}=1 \mathrm{~mm}$, $\mathrm{P}=80$ daN i różne prądy zgrzewania:

- (e4b) $\mathrm{i}=4.0 \mathrm{kA}$,

$-(\mathrm{e} 4 \mathrm{c}) \mathrm{i}=3.0 \mathrm{kA}$,

$-(\mathrm{e} 4 \mathrm{~d}) \mathrm{i}=2.0 \mathrm{kA}$. 


\section{Wyniki obliczeń numerycznych}

W tablicy II zestawiono wyniki dla różnych parametrów i wariantów obliczeń numerycznych.

Wyniki obliczeń numerycznych na poniższych rysunkach przedstawiono w układzie pionowym z uwagi na wykorzystanie do obliczeń standardowego modelu zgrzewania (w układzie pionowym).

Rysunek 1 przedstawia rozkład temperatury obszaru zgrzewania doczołowego prętów ze stali niskowęglowej i średnicy $\emptyset=6 \mathrm{~mm}$ dla długości mocowania prętów a) $12 \mathrm{~mm}$ i b) $4 \mathrm{~mm}$ dla różnych parametrów zgrzewania:

$\left.\left.-a_{1}\right), b_{1}\right) i=5.6 \mathrm{kA}, P=14 \mathrm{daN}$,

$\left.\left.-a_{2}\right), b_{2}\right) i=5.6 \mathrm{kA}, P=140 \mathrm{daN}$, $\left.\left.-a_{3}\right), b_{3}\right) i=16.8 k A, P=14$ daN,

$\left.\left.-a_{4}\right), b_{4}\right) i=16.8 \mathrm{kA}, P=140 \mathrm{daN}$.

Dla wszystkich przestawionych przypadków następuje nadtopienie materiału na całej powierzchni przekroju poprzecznego. Gwarantuje to uzyskanie poprawnego złącza zgrzewanego. Czasy zgrzewania dla krótszej długości mocowania prętów zgrzewanych $\left(\mathrm{I}_{\mathrm{z}}=4 \mathrm{~mm}\right)$ i niższych prądów zgrzewania (i=5.6 kA) są nieznacznie dłuższe $\left(a_{1} i b_{1}, a_{2}\right.$ i $\left.b_{2}\right)$ (odpowiednio - $5 \mathrm{~ms}$ i $10 \mathrm{~ms}$ ). Dla wyższych prądów (parametry twarde), niezależnie od długość mocowania prętów zgrzewanych $\left(\mathrm{I}_{\mathrm{z}}=12 \mathrm{~mm} \mathrm{i} \mathrm{I}_{\mathrm{z}}=4 \mathrm{~mm}\right)$ oraz siły docisku $(\mathrm{P}=14$ daN, $\mathrm{P}=140$ daN) czasy zgrzewania nie odbiegają od wartości $20 \mathrm{~ms}$.

Tablica II. Wyniki obliczeń numerycznych dla zgrzewania rezystancyjnego doczołowego prętów ( $\mathrm{f}=6 \mathrm{~mm}$, stal niskowęglowa) Table II. Results of numerical calculations for butt resistant welding of rods ( $\varnothing=6 \mathrm{~mm}$, low-carbon steel)

\begin{tabular}{|c|c|c|c|c|c|c|c|c|}
\hline Nazwa & $\begin{array}{l}\mathrm{L} 1 \\
{[\mathrm{~mm}]}\end{array}$ & $\begin{array}{l}\text { Prąd } \\
\text { zgrz. } \\
{[\mathrm{kA}]}\end{array}$ & $\begin{array}{c}\text { Siła } \\
\text { docisku } \\
\text { [daN] }\end{array}$ & $\begin{array}{c}\text { Czas } \\
\text { osiągnięcia } \\
\text { temp. } \\
1400\left[{ }^{\circ} \mathrm{C}\right]\end{array}$ & No. & $\begin{array}{l}\text { Skrócenie } \\
\text { prętów DI } \\
\text { [mm] }\end{array}$ & $\begin{array}{c}\text { Czas } \\
\text { do stopienia materiału } \\
\text { (w styku centralnym) } \\
{[\mathrm{ms}]}\end{array}$ & Uwagi \\
\hline 000 & $12+12$ & 5.6 & 14 & 87 & 522,528 & $0.0004 / 0.003$ & 175 & proces poprawny \\
\hline 001 & $12+12$ & 5.6 & 140 & 125 & 522,528 & $0.04 / 0.4$ & 265 & proces poprawny \\
\hline 010 & $12+12$ & 16.8 & 14 & 15 & 522,528 & $0.0003 / 0.0003$ & 20 & proces poprawny \\
\hline 011 & $12+12$ & 16.8 & 140 & 20 & 522,528 & $0.03 / 0.03$ & 21 & proces poprawny \\
\hline b1 & $12+12$ & 1.5 & 80 & 2360 & 522,528 & 1.37/--- & brak (t=3s) & brak przetopienia \\
\hline b2 & $12+12$ & 2.0 & 80 & 1160 & 522,528 & 0.46/--- & $\operatorname{brak}(\mathrm{t}=2 \mathrm{~s})$ & brak przetopienia \\
\hline b3 & $12+12$ & 3.0 & 80 & 455 & 522,528 & $0.09 / 2.8$ & 820 & proces poprawny \\
\hline b4 & $12+12$ & 4.0 & 80 & 240 & 522,528 & $0.02 / 0.75$ & 380 & proces poprawny \\
\hline c1 & $12+12$ & 1.5 & 80 & 2000 & 538,558 & 0.26/--- & $\operatorname{brak}(\mathrm{t}=2 \mathrm{~s})$ & brak przetopienia \\
\hline c2 & $12+12$ & 2.0 & 80 & 760 & 538,558 & 1.95/--- & $\operatorname{brak}(2 \mathrm{t}=\mathrm{s})$ & brak przetopienia \\
\hline c3 & $12+12$ & 3.0 & 80 & 142 & 538,558 & $1.55 / 2.94$ & 590 & proces poprawny \\
\hline c4 & $12+12$ & 4.0 & 80 & 64 & 538,558 & $1.4 / 2.8$ & 350 & proces poprawny \\
\hline 100 & $4+4$ & 5.6 & 14 & 120 & 508,514 & $0.0003 / 0.04$ & 180 & proces poprawny \\
\hline 101 & $4+4$ & 5.6 & 140 & 145 & 508,514 & $0.12 / 2.6$ & 275 & proces poprawny \\
\hline 110 & $4+4$ & 16.8 & 14 & -- & 508,514 & 0.0002 & 20 & proces poprawny \\
\hline 111 & $4+4$ & 16.8 & 140 & -- & 508,514 & 0.02 & 20 & proces poprawny \\
\hline e1 & $12+6$ & 5.6 & 80 & 131 & 486,492 & $0.07 / 0.15$ & 180 & proces poprawny \\
\hline e2 & $12+4$ & 5.6 & 80 & 128 & 592,585 & $0.07 / 0.13$ & 180 & proces poprawny \\
\hline e3 & $12+2$ & 5.6 & 80 & 128 & 603,593 & $0.06 / 0.11$ & 180 & proces poprawny \\
\hline e4 & $12+1$ & 5.6 & 80 & 207 & 496,482 & $0.21 / 0.24$ & 210 & proces poprawny \\
\hline e4b & $12+1$ & 4.0 & 80 & $\begin{array}{c}\max \text { temp } \\
1434 / 1356^{\circ} \mathrm{C}\end{array}$ & 496,482 & $---/ 0.55$ & 425 & $\begin{array}{l}\text { przesunięcie jądra } \\
\text { poza obszar styku }\end{array}$ \\
\hline e4c & $12+1$ & 3.0 & 80 & $\begin{array}{c}\max \text { temp } \\
1271 / 1151^{\circ} \mathrm{C}\end{array}$ & 496,482 & $---/--$ & -- & $\begin{array}{c}\text { przesunięcie } \\
\text { jądra poza obszar } \\
\text { styku } \mathrm{t}=1160 \mathrm{~ms}, \\
\mathrm{Dl}=4 \mathrm{~mm}\end{array}$ \\
\hline e4d & $12+1$ & 2.0 & 80 & $\begin{array}{c}\max \text { temp } \\
1144 / 870^{\circ} \mathrm{C}\end{array}$ & 496,482 & $---/--$ & -- & $\begin{array}{c}\text { brak przetopienia } \\
\mathrm{t}=2450 \mathrm{~ms} \\
\mathrm{DI}=4 \mathrm{~mm}\end{array}$ \\
\hline
\end{tabular}


Uwidacznia się wpływ (wydłużenia) czasu zgrzewania na odprowadzanie ciepła ze obszaru zgrzewania, co skutkuje wydłużeniem czasu zgrzewania dla uzyskania odpowiedniej strefy zgrzewania (nadtopienia) materiałów.

Zgrzewanie wyższym prądem pozwala na uzyskanie mniejszego skrócenia prętów bez względu na długość mocowania prętów. Z uwagi na bardzo krótki czas zgrzewania $(20 \mathrm{~ms})$ nie jest obserwowane odprowadzanie ciepła z obszaru zgrzewania i tym samym jego wydłużenie (jak dla parametrów miękkich tzn. niższy prąd i dłuższy czas).

Często z uwagi na ograniczenia mocy zgrzewarki podejmowane są próby zgrzewania parametrami poniżej wartości zalecanych [1,3]. Na rysunku 3 przedstawiono obrazy rozkładu temperatury dla prądów zgrzewania poniżej sugerowanych ( $\mathrm{i}=5.6 \mathrm{kA}$ ) od wartości 4 kA do $1.5 \mathrm{kA}$ i siły docisku $P=80$ daN oraz długości mocowania prętów $\mathrm{I}_{\mathrm{z}}=12 \mathrm{~mm}$. Dla kolejnych wariantów obliczeń przyjęto pośrednią wartość siły docisku pomiędzy zalecaną w poradniku [1] minimalną i maksymalną wartość tj. $\mathrm{P}=80 \mathrm{daN}$.

Dla prądu zgrzewania $i=4.0 \mathrm{kA}$ oraz $\mathrm{i}=3.0 \mathrm{kA}$ następuje przetopienie materiału na całym przekroju styku materiałów zgrzewanych. Parametry te moż- na by uznać również za poprawne. Jednak z uwagi na mniejszy prąd zgrzewania wydłużony zostaje czas zgrzewania ( $\mathrm{t}_{\mathrm{zgrz}}=265 \mathrm{~ms}-$ rys. $1 \mathrm{a} 2$, do $\mathrm{t}_{\mathrm{zgrz}}=380 \mathrm{~ms}$ - rys. 3.c4 $\mathrm{i} \mathrm{t}_{\mathrm{zgrz}}=455 \mathrm{~ms}$ rys. 3.c4) (porównania dokonano dla różnych sił docisku $\mathrm{P}=140 \mathrm{daN}$ i $\mathrm{P}=80 \mathrm{daN}$ ).

Natomiast dla wartości prądu $t_{\text {zgrz }}=2.0 \mathrm{kA} \mathrm{i} t_{\text {zgrz }}$ $=1.5 \mathrm{kA}$ nie następuje nadtopienia materiałów nawet dla czasu trwania procesu $\mathrm{t}_{\mathrm{zgrz}}=2.0 \mathrm{~s}\left(\right.$ dla $\mathrm{i}_{\mathrm{zgrz}}=2.0 \mathrm{kA}$ ) $i t_{z g r z}=3.0 \mathrm{~s}$ (dla $i_{\text {zgrz }}=1.5 \mathrm{kA}$ ). Obliczenia numeryczne były prowadzone do czasu aż punkty leżące $\mathrm{w}$ obszarze przystykowym osiągną temperaturę $1400{ }^{\circ} \mathrm{C}$. Taka temperatura pozwala na uzyskanie połączenia w stanie stałym o odpowiedniej wytrzymałości (ok. 80\% wytrzymałości nominalnej).

Obniżenie jednak wartości prądu zgrzewania skutkuje spadkiem jego gęstości i wydłużeniem czasu zgrzewania (rys. $3 \mathrm{c} 1 . \mathrm{t}_{\mathrm{zgrz}}=2369 \mathrm{~ms}$ dla $\mathrm{i}_{\text {zgrz }}=1.5 \mathrm{kA}$ i rys. $3 c 2 . t_{z g r z}=1160 \mathrm{~ms}$ dla $i_{\text {zgrz }}=2.0 \mathrm{kA}$ ). Środkiem zaradczym może być odpowiednie przygotowanie powierzchni czołowej prętów (rys. 3d1-d4). Zabieg taki pozwala na koncentrację energii, szczególnie w początkowej fazie zgrzewania. Pozwala to na skrócenie czasu zgrzewania (rys. $3 \mathrm{c} 1$ i rys. $3 \mathrm{~d} 1 \mathrm{z} \mathrm{t}_{\mathrm{zgrz}}=2360$ $\mathrm{ms}$ do $\mathrm{t}_{\mathrm{zgrz}}=2000 \mathrm{~ms}$, rys. 32 i rys. $3 \mathrm{~d} 2 \mathrm{z} \mathrm{t}_{\mathrm{zgrz}}=1160 \mathrm{~ms}$ do $\left.\mathrm{t}_{\mathrm{zgrz}}=760 \mathrm{~ms}\right)$.

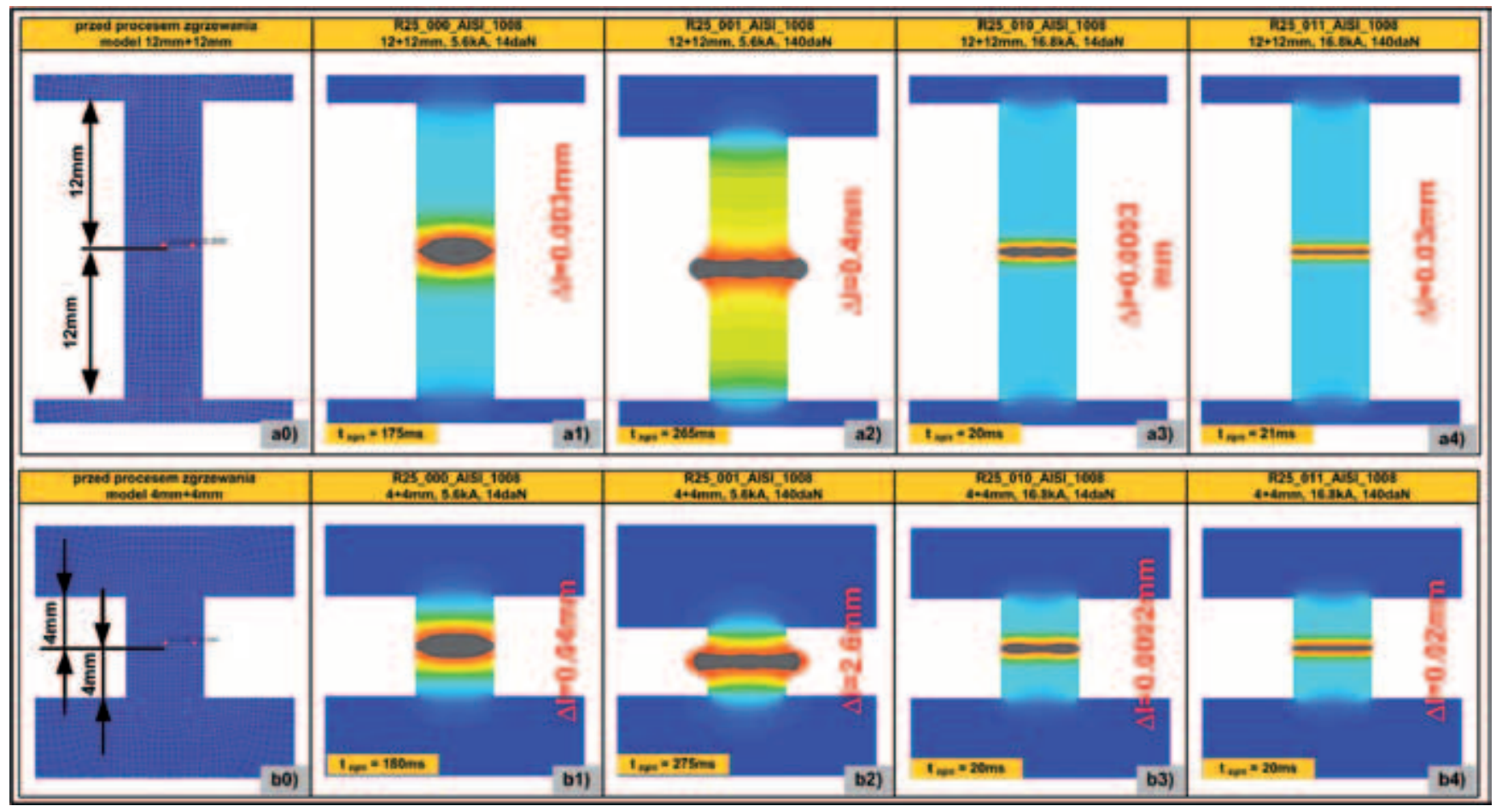

Rys. 2. Rozkład temperatury obszaru zgrzewania doczołowego prętów (stal niskowęglowa, $\emptyset=6 \mathrm{~mm}$ ) dla długości mocowania prętów: a) $\left.\mathrm{I}_{\mathrm{z}}=12 \mathrm{~mm}, \mathrm{~b}\right) \mathrm{I}_{\mathrm{z}}=4 \mathrm{~mm}$ i odpowiednio parametrach zgrzewania:

$\left.-a_{0}\right), b_{0}$ ) widok siatki i wymiary elementów zgrzewanych modelu obliczeniowego,

- a1), b1) i=5.6kA, $P=14 \mathrm{daN}$,

-a2), b2) i=5.6kA, $P=140 \mathrm{daN}$,

- a3), b3) i=16.8kA, $P=14 \mathrm{daN}$,

a4), b4) $i=16.8 \mathrm{kA}, \mathrm{P}=140 \mathrm{daN}$.

Fig. 2. Temperature distribution in the butt welding area of rods (low-carbon steel, $\varnothing=6 \mathrm{~mm}$ ) for a rod fixing length of : a) $l z=12 \mathrm{~mm}, b$ ) $l z=4 \mathrm{~mm}$ and welding parameters respectively:

-a0), b0) mesh and dimensions of elements welded for the computational model,

- a1), b1) i=5.6kA, $P=14 \mathrm{daN}$,

a2), b2) i=5.6kA, $P=140 \mathrm{daN}$,

a3), b3) $i=16.8 \mathrm{kA}, P=14 \mathrm{daN}$,

a4), b4) i=16.8kA, $P=140 \mathrm{daN}$. 


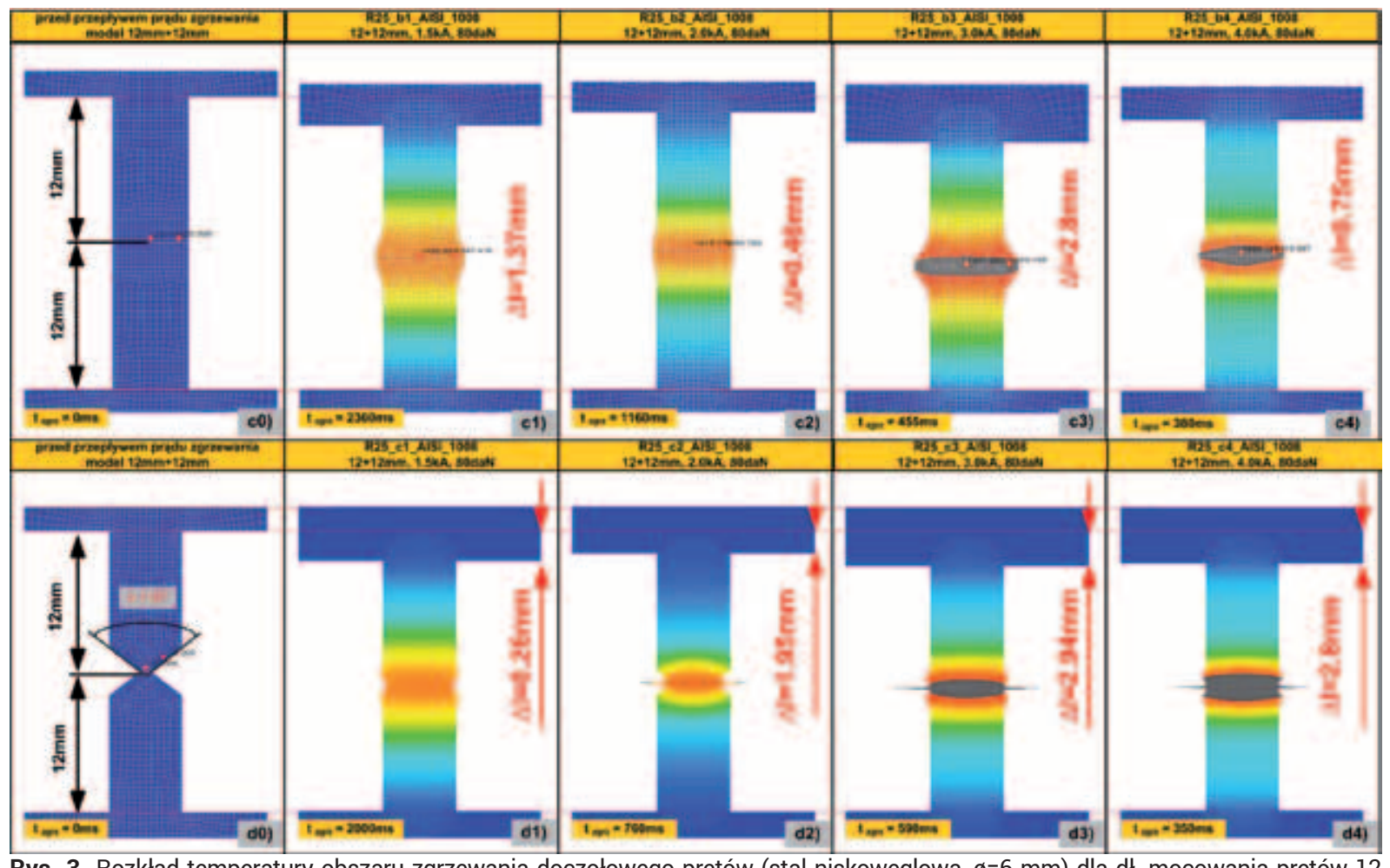

Rys. 3. Rozkład temperatury obszaru zgrzewania doczołowego prętów (stal niskowęglowa, $\emptyset=6 \mathrm{~mm}$ ) dla dł. mocowania prętów 12 $\mathrm{mm}$ i różnym zakończeniu powierzchni czołowej prętów: c) płaska d) ukosowana (kąt $\alpha=110^{\circ}$ ) i odpowiednio parametrach zgrzewania: - $\left.\mathrm{c}_{0}\right), \mathrm{d}_{0}$ ) widok siatki i wymiary elementów zgrzewanych modelu obliczeniowego,

- c1), d1) i=5.6 kA, $P=80 \mathrm{daN}$,

- c2), d2) i=5.6 kA, $P=80 \mathrm{daN}$,

- c3), d3) i=16.8 kA, $P=80$ daN,

- c4), d4) $i=16.8 \mathrm{kA}, \mathrm{P}=80 \mathrm{daN}$.

Fig. 3. Temperature distribution in the butt welding area of rods (low-carbon steel, $\varnothing=6 \mathrm{~mm}$ ) for a rod fixing length of $12 \mathrm{~mm}$ and various rod butting face finish: $c$ ) flat d) bevelled (angle $\alpha=110^{\circ}$ ) and welding parameters respectively:

$\left.\left.-c_{0}\right), d_{0}\right)$ mesh and dimensions of elements welded for the computational model,

- c1), d1) i=5.6 kA, $P=80$ daN,

- c2), d2) i=5.6 kA, $P=80$ daN,

- c3), d3) $i=16.8 \mathrm{kA}, P=80 \mathrm{daN}$,

- c4), d4) i=16.8 kA, $P=80$ daN.

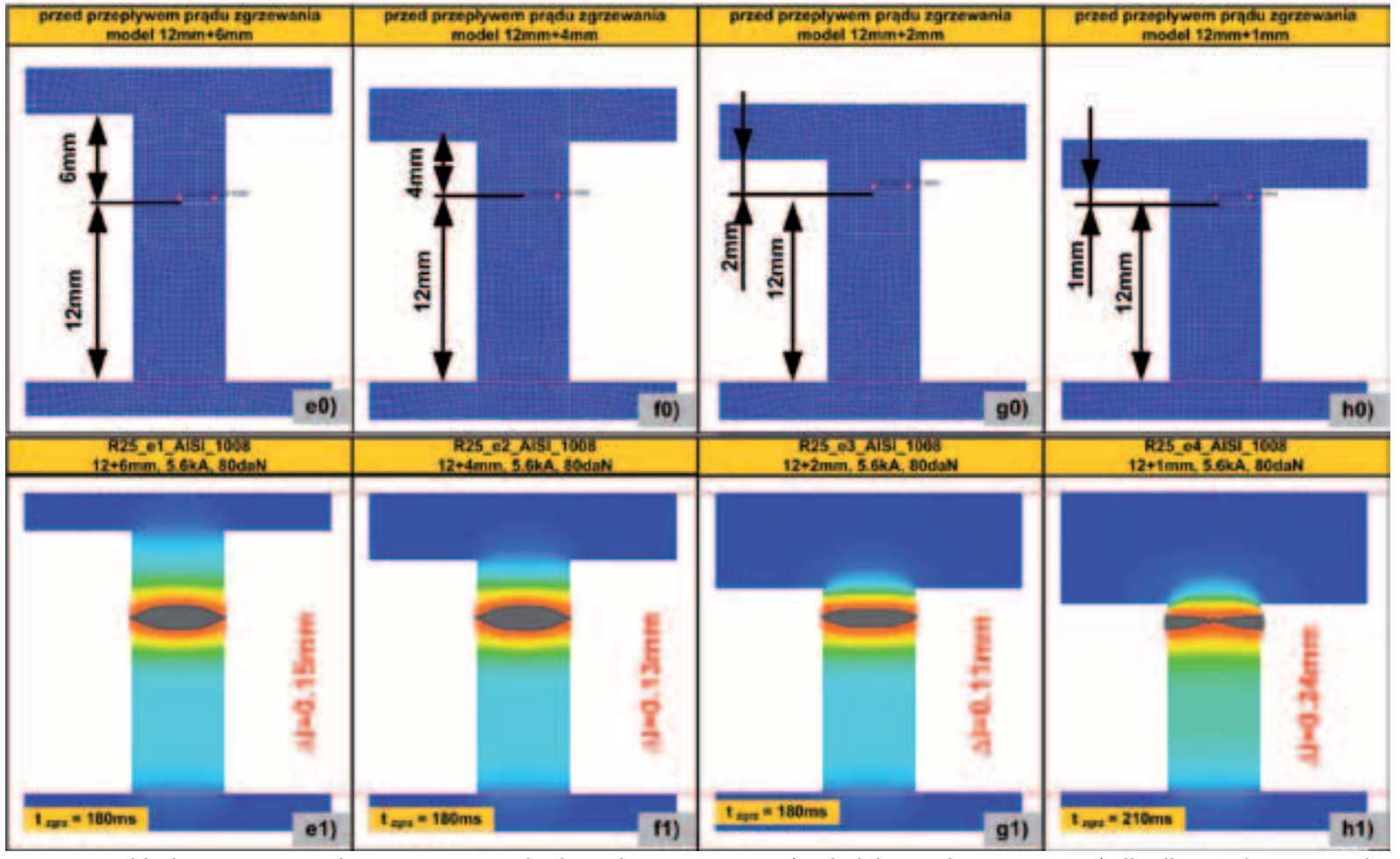

Rys. 4. Rozkład temperatury obszaru zgrzewania doczołowego prętów (stal niskowęglowa, $\emptyset=6 \mathrm{~mm}$ ) dla długości mocowania: pręt nr $1-12 \mathrm{~mm}$, pręt nr 2 - odpowiednio e) $6 \mathrm{~mm}$, f) $4 \mathrm{~mm}, \mathrm{~g}) 2 \mathrm{~mm}, \mathrm{~h}) 1 \mathrm{~mm}$ i parametrach zgrzewania $\mathrm{i}_{\text {zgrz }}=5.6 \mathrm{kA}, \mathrm{P}=80 \mathrm{daN}$. Fig. 4. Temperature distribution in the butt welding area of rods (low-carbon steel, $\varnothing=6 \mathrm{~mm}$ ) for a fixing length: rod no. $1-12 \mathrm{~mm}$, rod no. 2 - respectively e) $6 \mathrm{~mm}$, f) $4 \mathrm{~mm}, \mathrm{~g}) 2 \mathrm{~mm}$, h) $1 \mathrm{~mm}$ and welding parameters $\mathrm{i}_{\text {weld }}=5.6 \mathrm{kA}, \mathrm{P}=80 \mathrm{daN}$ 
Na rysunku 4 analizowano efekt niesymetrycznego zamocowania prętów. Dla przypadków zgrzewania minimalnym prądem (5.6 kA) według wytycznych zawartych $w$ pracy [1] i dla założonej średnicy prętów $(\varnothing=6.0 \mathrm{~mm})$ dla przypadków e1, e2 i e3 czas zgrzewania jest dokładnie taki sam. Dopiero dla bardzo dużej niesymetrii $\left(l_{1}=12 \mathrm{~mm}, \mathrm{l}_{2}=1 \mathrm{~mm}\right)$ wymagany czas zgrzewania wzrasta o $17 \%\left(\mathrm{z} \mathrm{t}_{\mathrm{zgrz}}=180 \mathrm{~ms}\right.$ do $\mathrm{t}_{\mathrm{zgrz}}=210 \mathrm{~ms}$ ). Dodatkowo obserwowany jest odmienny sposób kształtowania jądra zgrzeiny od zewnątrz do środka pręta. Ponadto materiał dłuższego pręta ulega większemu stopieniu.

Ten przypadek (niesymetrii zamocowania prętów $\mathrm{I}_{1}=12 \mathrm{~mm}, \mathrm{l}_{2}=1 \mathrm{~mm}$ ) dla prądu zgrzewania $\mathrm{i}_{\text {grz }}=5.6 \mathrm{kA}$ i mniejszych jego wartości przeanalizowano na rysunku 5.

Rysunki 5i1 - i4 obrazują sposób kształtowania się roztopionego materiału jądra dla prądu zgrzewania $\mathrm{i}=5.6 \mathrm{kA}$ od zewnątrz do wewnątrz. Dla zmniejszającej się wartości prądu zgrzewania obserwujemy zmianę charakteru nagrzewania się obszaru przystykowego. Materiał nagrzewa się od środka.

Dla prądu zgrzewania $\mathrm{i}_{\text {zgrz }}=4.0 \mathrm{kA}$ rysunki $5 \mathrm{j} 1$ - j4 mate- riał zostaje przetopiony na całym przekroju poprzecznym prętów. Obserwowany jest również silniejszy efekt przesunięcia płaszczyzny topienia materiałów od strefy styku prętów zgrzewanych w kierunku dłuższego pręta. Jest to wynik wydłużenia czasu zgrzewania i mniej intensywnego odprowadzania ciepła przez dłuższy pręt stalowy w stosunku do elektrod miedzianych.

Dla prądu zgrzewania $\mathrm{i}_{\text {zgrz }}=3.0 \mathrm{kA}$ rys. $5 \mathrm{k} 1$ - $\mathrm{k} 4$ materiał topi się na początku w środkowej strefie ale nie zostaje przetopiony na całym przekroju poprzecznym prętów dla założonego dopuszczalnego skróceniu długości prętów $(\Delta \mathrm{s}=4.2 \mathrm{~mm})$. Wraz ze zmniejszeniem wartości prądu zgrzewania efekt przesunięcia roztopionego materiału od płaszczyzny styku (prętów) nasila się coraz bardziej. Dodatkowo temperatura punktów leżąca w obszarze przystykowym w materiale krótszego pręta ulega obniżeniu poniżej $1400^{\circ} \mathrm{C}$. Dla dalszego zmniejszania prądu zgrzewania $\mathrm{i}_{\text {zgrz }}=2.0$ kA rys. 5l1 - 14 nie jest w ogóle obserwowane nadtopienie prętów, a temperatura w analizowanych punktach spada poniżej $900^{\circ} \mathrm{C}$. Prowadzi to do braku zgrzania materiałów zgrzewanych (prętów).

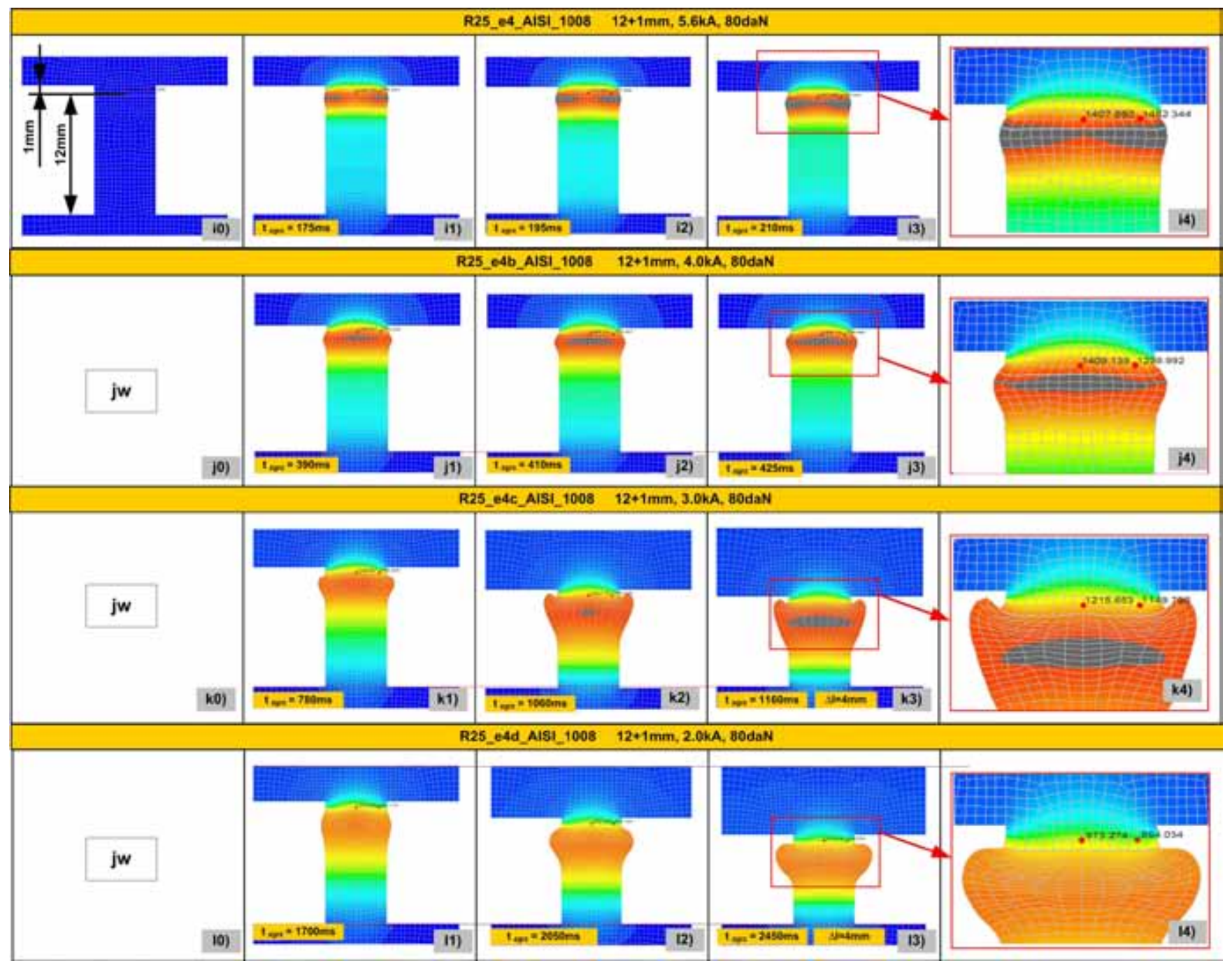

Rys. 5. Rozkład temperatury obszaru zgrzewania doczołowego prętów (stal niskowęglowa, $\varnothing=6 \mathrm{~mm}$ ) dla długości mocowania: pręt $\mathrm{nr} 1-12$ $\mathrm{mm}$, pręt $\mathrm{nr} 2-1 \mathrm{~mm}$ i różnym prądzie zgrzewania i) $5.6 \mathrm{kA}$, j) $4.0 \mathrm{kA}, \mathrm{k}$ ) $3.0 \mathrm{kA}$, l) $2.0 \mathrm{kA}$ dla siły docisku $\mathrm{P}=80 \mathrm{daN}$

Fig. 5. Temperature distribution in the butt welding area of rods (low-carbon steel, $\varnothing=6 \mathrm{~mm}$ ) for a fixing length: rod no. $1-12 \mathrm{~mm}$, rod no. $2-1$ $\mathrm{mm}$ and various welding current i) $5.6 \mathrm{kA}, \mathrm{j}) 4.0 \mathrm{kA}, \mathrm{k}$ ) $3.0 \mathrm{kA}$, l) $2.0 \mathrm{kA}$ for a pressure force $\mathrm{P}=80 \mathrm{daN}$ 


\section{Wnioski}

Zgrzewanie doczołowe prętów na przykładzie wybranej średnicy $\emptyset=6.0 \mathrm{~mm}$ zgodnie z zaleceniami [1] pozwala na bardzo szeroką zmianę gęstości prądu zgrzewania od $\mathrm{j}_{\text {zgrz }}=200-600 \mathrm{~A} / \mathrm{mm}^{2}$. Odpowiada to minimalnej i maksymalnej wartości prądu zgrzewania odpowiednio $i_{\text {zgrz }}=5.6 \mathrm{kA} \mathrm{i}_{\text {zgrz }}=16.8 \mathrm{kA}$. W wyniku obliczeń numerycznych przeanalizowano przebieg procesu i stwierdzono poprawność tworzenia złącza (uzyskanie przetopienia materiału) o poprawnej budowie dla założonego okna dopuszczalnych parametrów $\left(\mathrm{i}_{\mathrm{zgrz}}=5.6 \mathrm{kA}-16.8 \mathrm{kA}\right.$, Pdocisku 14 daN - 140 daN) (rys. 1a1-a4).

Dla jednoimiennej konfiguracji materiałów zgrzewanych (w analizowanym przypadku stal niskowęglowa AISI 1008) istnieje szerokie pole parametrów zgrzewania tablica II wiersz 1-4, 7,8, 11-30. Natomiast krytycznym staje się zbyt niski prąd zgrzewania tablica II wiersz 5,6 oraz zbyt duża asymetria wysunięcia prętów ze szczęk tablica II wiersz 21-23.

Często jednak w praktyce stosuje się gęstości prądu zgrzewania znacznie niższe z uwagi na ograniczoną moc zgrzewarki. Powoduje to utrudnienie w samym przebiegu procesu zgrzewania i uzyskanie poprawnego złącza zgrzewanego. Niekorzystny efekt kształtowania się jądra zgrzeiny (roztopiony materiał elementów zgrzewanych) nasila się szczególnie przy niesymetrycznym zamocowaniu elementów zgrzewanych (prętów) w szczękach mocujących (elektrodach) zgrzewarki (różne długości wysunięcia prętów ze szczek). Prowadzi to w efekcie do uzyskania najwyższej temperatury poza miejscem styku powierzchni czołowych elementów (rys. 4j4 i 4k4). W związku z tym własności wytrzymałościowe otrzymywanych złączy zgrzewanych dalekie są od wartości oczekiwanych.

Komentarza wymaga parametr maksymalnego czas zgrzewania dopuszczany dla zgrzewania prętów dla stali niskowęglowej, o wartości 15 sekund. Z uwagi na fakt, że w pracy [1] maksymalny dopuszczalny czas dla innych materiałów zgrzewanych $\mathrm{np}$. miedzi czy aluminium wynosi odpowiednio 15 sek i 6 sek istnieje przypuszczenie, że został popełniony błąd drukarski. Obliczenia numeryczne (na przykładzie wybranego gatunku materiału - stali niskowęglowej i średnicy $\emptyset=6.0 \mathrm{~mm}$ ) oraz przeprowadzone badania eksperymentalne potwierdzają uzyskanie poprawnych złączy zgrzewanych nawet dla najmniejszego dopuszczalnego prądu zgrzewania $\left(i_{\text {zgrz }}=5.6 \mathrm{kA}\right) \mathrm{w}$ czasie $\mathrm{t}_{\text {zgrz }}=256 \mathrm{~ms}$ (rys. 1a2).

Istotnym zagadnieniem $\mathrm{w}$ procesie łączenia prętów różniących się opornością elektryczną (częste przypadki) jest określenie właściwej wartości wysunięcia prętów ze szczek mocujących w celu uzyskania równej ich oporności. Umożliwia to wówczas uzyskanie w miejscu płaszczyzny styku łączonych doczołowo prętów najwyższej temperatury nagrzania wpływającej na własności wytrzymałościowe złącza. Dokładne ustalenie wartości wysunięcia prętów ze szczek mocujących dla przyjętych parametrach elektrycznych zgrzewania umożliwia analiza symulacyjna MES przebiegu procesu.

\section{Literatura}

[1] Poradnik Inżyniera, Spawalnictwo tom 2 WNT Warszawa $2005 \mathrm{r}$.

[2] www.swantec.com
[3] H. Papkala: „Zgrzewanie oporowe metali”, wydawnictwo KaBe Krosno 2003 r. 